\title{
EFFECT OF PALM OIL SUPPLEMENTATION ON MILK YIELD, MILK CONSTITUENTS, DIGESTIBILITY AND SOME BLOOD METABOLITES OF LACTATING BUFFALOES
}

\author{
S.T.M. Fahmy, K.I. Abd-Elmoty, S.M.S. Moustfa, E.B. Soliman and E.M. Ibrahim \\ Animal Production Department, Faculty of Agriculture, Minia University, Minia, Egypt \\ E-mail of the corresponding author is: dr_samir_fahmy@yahoo.com
}

(Received 24/11/2015, accepted 4/2/2016)

\section{SUMMARY}

$\mathbf{S}$ ix lactating Egyptian buffaloes of $410 \pm 16 \mathrm{~kg}$ body weight were used in this study. They were fed according to Agriculture and food research council (AFRC) metabolisable energy requirement plus 0,10 and $15 \%$ of their metabolisable energy requirement as palm oil. It was supplemented to the concentrate mixture to increase the dietary energy density to know if the poor productivity of our buffaloes is due to their gene make up or their requirement of energy is not covered. Milk yield, milk constituents, digestibility and some blood metabolites as affected by palm oil supplementation were studied. A balanced two period's changeover design for several treatments was applied. Results indicated that total dry matter intake was insignificantly increased by 2.80 and $10.97 \%$ due to 10 and $15 \%$ palm oil supplementation. Total digestible nutrients were significantly $(\mathrm{P}<0.05)$ improved by 5.76 and $10.56 \%$ due to palm oil supplementation. Milk yield of $7 \%$ fat corrected milk was enhanced significantly $(\mathrm{P}<0.05)$ by 27.86 and $52.95 \%$ as buffaloes were fed the energy supplemented rations. The milk fat yield was significantly $(\mathrm{P}<0.05)$ increased by 28.72 and $56.14 \%$ due to fat supplementation. At the same trend milk protein yield was increased by 19.65 and $31.44 \%$ due to fat supplementation. The differences were significant $(\mathrm{P}<0.05)$. The positive effects of palm oil supplementation on blood glucose, protein and total lipids were studied. The AFRC standards are not sufficient to cover the metabolisable energy requirements for our lactating buffaloes and metabolisable energy supplementation up to $15 \%$ is beneficial.

Keywords: fat; milk; digestibility; blood; buffalo

\section{INTRODUCTION}

Buffalo's milk contributes about $46.96 \%$ of the total milk produced in Egypt (Ministry of Agriculture, 2011). Among the environmental factors affecting milk production is the feed quality and quantity offered. The metabolisable energy (ME) requirements of lactating buffaloes in Egypt are not clearly defined. Paul et al., (2002) reported that there being wide differences as great as $40 \%$ in nutrient requirement prescribed by various feeding standards (Kearl, 1982 and Pathak and Verma, 1993). Even though there are little amount of individual research work to increase productivity of lactating buffaloes (El-Ashry et al.,1992 and Bayoumi,1995, Nanda and Nakao,2003 and Nawaz et al.,2012,). Increasing milk production of cattle through increasing dietary energy level is recognized in enhancing lactation potential (NRC, 2001 and Ibrahim, 2001, Mahendra Singh, et al., 2014 and Rajesh et al., 2014). Increasing dietary energy density through fat supplementation is the simplest procedure to avoid excess amount of carbohydrate with its concomitant problems of acidosis, greater heat loss as methane, increase feed bulk in the gastrointestinal tract and change the balance of other feed nutrients. Supplemental fat sources are utilized in rations of dairy cows as a common method to increase the energy density of the ration to support energy demand for milk synthesis (Juchem et al., 2008, Rabiee et al., 2012). Drackley et al. (2003) and Tripathi, (2014) stated that supplemental fat had modest advantage over addition of starch based concentrate during summer heat condition. Our objectives, were studying the effect of palm oil (PO) supplementation to lactating buffaloes ration in amounts that represent 0,10 and $15 \%$ above their AFRC, (1993) ME requirements on feed intake, digestibility, feeding value, milk yield, milk constituents and some blood metabolites. 


\section{MATERIALS AND METHODS}

This experiment was carried out at the experimental farm of Animal Production Department, Faculty of Agriculture, Minia University, Egypt from January - march, 2007.

\section{Animals and experimental design}

$\mathrm{S}$ ix Egyptian buffaloes $(410 \pm 16 \mathrm{~kg})$ body weight were used in this study of three treatments. Animals were used at three months after calving (mid lactation) they were used in a balanced two-period changeover design for several treatments (Gill and Magee, 1976). At the beginning, buffaloes were randomly allocated to three dietary treatments, two buffaloes per treatment /period (Table 1).

Table (1): Distribution of buffaloes fed the different treatments through the two periods.

\begin{tabular}{|c|c|c|c|c|c|c|}
\hline \multicolumn{2}{|l|}{ Period } & \multicolumn{5}{|c|}{ 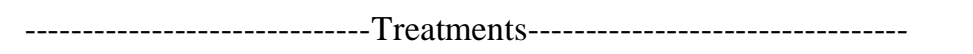 } \\
\hline $\mathrm{P} 1$ & $\mathrm{~T} 1$ & $\mathrm{~T} 2$ & $\mathrm{~T} 1$ & T3 & $\mathrm{T} 2$ & T3 \\
\hline $\mathrm{P} 2$ & $\mathrm{~T} 2$ & $\mathrm{~T} 1$ & $\mathrm{~T} 3$ & $\mathrm{~T} 1$ & $\mathrm{~T} 3$ & $\mathrm{~T} 2$ \\
\hline Buffaloes & 1 & 2 & 3 & 4 & 5 & 6 \\
\hline
\end{tabular}

T1, T2 and T3 represent the three tested rations.

$P 1$ and $P 2$ represent the two periods in the experimental design.

The experiment consisted of two periods (P1 and P2) each of 30 days (23 days for adaptation and 7 days for milk, blood and feces samples collection). At the end of the first period buffaloes were reassigned to the experimental treatments for another 30 days period (the second period P2). This means that four animals were fed each treatment for 30 days. The animals were weighed at the beginning and the end of each period. Tomlinson et al., (1994) demonstrated that Latin square designs with 28 days period are adequate for detection of milk production responses to supplemental fat without carryover effects.

\section{Feeding and management}

The buffaloes were housed inside stable for individual feeding. Fresh water was available along the experiment. The fat supplement was mixed with the CM by hand just before feeding. Buffaloes were milked at 7 a.m. and 5 p.m. They were fed individually at 8 a.m. and 6 p.m. Excess amounts of SCB were offered and the residues were weighed before the next feeding. Buffaloes were subjected to routinely veterinary vaccination and inspection system throughout the experimental period.

\section{Experimental rations}

Three rations were formulated to meet 100, 110 and $115 \%$ of the buffaloes ME requirements according to AFRC (1993) recommendations for dairy cattle. Palm oil (PO) from Alpha chemical, Egyptian company, as a pure source of fat was added to the control concentrate mixture (CM) in amounts that represent 0,10 and $15 \%$ of the buffaloes ME requirements. The percentages of fatty acids methyl esters of the CM and the palm oil (PO) are presented in Table (2).

These three treatments were nominated as T1, T2 and T3, respectively. The control CM provides 11.23 MJ ME / kg DM (calculated from the tabulated figures for each component, AFRC, 1993). The second treatment (T2) composed of $\mathrm{T} 1+3.4 \% \mathrm{PO}$ to rise the ME concentration up to $12.35 \mathrm{MJ} / \mathrm{kg} \mathrm{DM}$ (110\% of T1). The third treatment T3 was T1+ 5.24\% PO to rise the ME concentration up to $12.92 \mathrm{MJ} /$ $\mathrm{kg}$ DM (115\% of T1). All these experimental concentrate mixtures were isonitrogenous (172.5 g crude protein (CP) / kg DM, $91.44 \mathrm{~g}$ metabolisable protein (MP) / $\mathrm{kg} \mathrm{DM}$ ) calculated according to the tabulated value of each component (AFRC, 1993).

The CM (T1) was composed from $43.25 \%$ un-decorticated cotton seed meal, $29.5 \%$ wheat bran, $8.75 \%$ yellow corn, $3.75 \%$ rice bran, $11 \%$ molasses, $2.5 \%$ calcium carbonate and $1.25 \%$ sodium chloride.

Sugar cane bagasse (SCB) as a roughage source was offered ad-libitum and the amount consumed was considered in calculating the total DM intake. Commercial trace minerals mixture (Table 3) was mixed with the $\mathrm{CM}$ as $1 \mathrm{~kg} / \mathrm{ton}$. Licking salt blocks were also available. Muscular injections of vitamins $\mathrm{A}, \mathrm{D}_{3}$ and $\mathrm{E}$ (Advit $\mathrm{C}$, trade name) were given every two weeks according to NRC (2001) standards. Each ml-liter contains 100000 I.U. vitamin A, 10000 I.U. vitamin $\mathrm{D}_{3}, 60 \mathrm{mg}$ vitamin $\mathrm{E}$ and $200 \mathrm{mg}$ vitamin C. 
Egyptian J. Nutrition and Feeds (2016)

Table (2): Percentage of fatty acids methyl esters of concentrate mixture and palm oil

\begin{tabular}{ccc}
\hline Fatty acids & Concentrate mixture & Palm oil \\
\hline C8:0 & 4.21 & 2.67 \\
C10:0 & 2.67 & 2.01 \\
C12:0 & 11.83 & 5.27 \\
C14:0 & 5.88 & 2.51 \\
C16:0 & 23.32 & 27.63 \\
C16:1 & 0.38 & 1.67 \\
C18:0 & 5.18 & 3.27 \\
C18:1 & 23.04 & 35.79 \\
C18:2 & 21.23 & 17.41 \\
C18:3 & 1.14 & 1.67 \\
C20:0 & 1.14 & $\ldots \ldots$ \\
\hline Total saturated & 54.22 & 5 \\
Total unsaturated & 45.78 & 53.4 \\
\hline
\end{tabular}

Table (3): Composition of commercial mineral mixture added to the concentrate mixture*

\begin{tabular}{lccc}
\hline Mineral & $\mathrm{g} / \mathrm{kg}$ & Trace mineral & $\mathrm{mg} / \mathrm{kg}$ \\
\hline Calcium & 59.7 & Iron & 921 \\
Phosphorus & 45.9 & Zinc & 1240 \\
Sodium & 40.5 & Copper & 400 \\
Magnesium & 2.2 & Selenium & 4.6 \\
& & Iodine & 63.8 \\
& & Manganese & 1011 \\
\end{tabular}

"Muvco, Ismailia, Egypt.

\section{Sampling and laboratory analysis}

Dietary samples were collected daily in the last week of each period and a composite sample was performed. Portion of the composite sample was dried at $105{ }^{\circ} \mathrm{C}$ in a forced air oven till constant weight for DM determination. The rest of the composite sample was dried at $70^{\circ} \mathrm{c}$ for constant weight, grind and stored at room temperature in a closely tied jar for laboratory analysis.

Fatty acids methyl esters of the CM and PO were detected using gas chromatography. Gas chromatography model, Shimadzu-8A, equipped with FID detector and glass column 2.5 X $3 \mathrm{~m}$ m I'd, under the following conditions : Column 5\% DEGS on 80/100 Chromo Q, Column temperature (Tem.) $150-180 \mathrm{C}^{\circ}$ at rate $2 \mathrm{C}^{\circ} / \mathrm{min}$. Detector tem. $270{ }^{\circ} \mathrm{C}, \mathrm{N} 2$ flow rate: $20 \mathrm{ml} / \mathrm{min}$, $\mathrm{H} 2$ flow rate: $75 \mathrm{ml}$ /min., Air flow rate: $0.5 \mathrm{ml} / \mathrm{min}$, Sensitivity: $16 \times 10^{2}$, Shart speed: $2.5 \mathrm{~m} \mathrm{~m} / \mathrm{min}$. (Radwan, S. S., 1978).

Dry matter (DM), crude protein (CP), ether extracts (EE) and ash of feeds and fecal samples were determined according to A.O.A.C. (1990). Neutral detergent fibre (NDF) and acid detergent fibre (ADF) were determined according to Van Soest et al., (1991). Carbohydrate (CHO) was calculated as DM - (CP $+\mathrm{EE}+\mathrm{ash}$ ). Hemicellulose was calculated by difference (NDF-ADF). Non fibrous carbohydrate (NFC) was calculated according to NRC (2001). Total tract digestibility of DM, OM, CP, EE, CHO, NFC, NDF and ADF were determined using acid insoluble ash as an internal marker as outlined by Van Keulen and Young (1977). Milk yield was recorded daily and milk samples (10 ml/kg milk produced) from morning and afternoon milking were collected from each animal on days 24 and 27 of each period and analyzed individually for total solids, total nitrogen and ash according to A.O.A.C (1990). The milk fat was measured by Gerber unites (British standards institution, 1962). Milk yield was corrected for $7 \%$ fat using the formula of Raafat and Saleh (1962). 7\% fat corrected milk $(7 \%$ FCM $)=0.265 *$ milk yield + $10.5^{*}$ fat yield. At the end of each period, heparinized blood samples were collected from the jugular vein of each animal at 8 am before animals access to feed. Plasma samples were obtained by centrifugation of heparinized blood samples at 3000r.p.m. for 10 minutes and stored at $-20{ }^{\circ} \mathrm{C}$ until analysis. Plasma triiodothyronine $\left(\mathrm{t}_{3}\right)$ and thyroxine $\left(\mathrm{t}_{4}\right)$ concentrations were determined by a direct solid-phase $\mathrm{I}^{125}$ radio immunoassay techniques using (coat-A-count $\mathrm{TKT}_{3}$ and $\mathrm{TKT}_{4}$ ) RIA Kits purchased from diagnostic 


\section{Fahmy et al.}

products corporation (DPC, Los Angeles, CA, 90045-5597,USA). Plasma glucose (mg/dl), cholesterol $(\mathrm{mg} / \mathrm{dl})$, and triglycerides $(\mathrm{mg} / \mathrm{dl})$ were determined using bio-Merieux Kits (marcy-1, Etolie Charbnniere -Les-Bains,France).Plasma total protein $(\mathrm{g} / \mathrm{dl})$, albumin $(\mathrm{g} / \mathrm{dl})$ and total lipids $(\mathrm{mg} / \mathrm{dl})$ were determined using Bio- Analytics Kits (USA). Plasma globulin was calculated as (total protein - albumin).

\section{Statistical analysis}

A balanced two period's changeover design for several treatments was used to analyze the data. The major appeal of the designs is that they permit one to obtain relatively precise results with few animals. Each animal is exposed to a sequence of two or more treatments in successive experimental periods. The variation within animals normally is much less than the variation among animals (Gill and Magee, 1976). The linear model for the experimental response variables is:

$$
\mathrm{Y}_{\mathrm{ijk}}=\mu+\mathrm{A}_{\mathrm{i}}+\mathrm{B}_{\mathrm{j}}+\mathrm{T}_{\mathrm{k}}+\mathrm{E}_{\mathrm{ijk}}
$$

Where $\mu$ is the overall mean, $A$ is the random effect of buffalo ( $\mathrm{i}=1 \ldots . .6$ ), $\mathrm{B}$ is the fixed effect of experimental period $(\mathrm{j}=1$ and 2$), \mathrm{T}$ is the effect of treatment $(\mathrm{k}=1 \ldots .3)$ and $\mathrm{E}$ is the experimental error $\left(0, \delta^{2}\right)$. Duncan's multiple range test was used to determine the significance among treatment means using GLM procedure of SAS (1990).

\section{RESULTS AND DISCUSSION}

The nutritional analysis of the experimental CM and SCB (g/kg DM) are presented in Table (4). The control CM used in this experiment contained 172.5 g CP, 392.1 g NDF, 232.5 g ADF and 297.9 g NFC /kg DM. These figures were comparable to that recorded in NRC (2001) for dairy cattle. The recommended figures were $140-180 \mathrm{~g} \mathrm{CP}, 250-330 \mathrm{~g} \mathrm{NDF}, 170-210 \mathrm{~g}$ ADF as minimum concentration and $320-430 \mathrm{~g}$ NFC as maximum concentration /kg DM. Also, Ranjhan (1980) concluded that the CP content of lactating buffaloes concentrate mixture ranged from $140-160 \mathrm{~g} / \mathrm{kg} \mathrm{DM}$. Nawaz, et al.(2012) fed Nili-Ravi buffalo on diets contain $12.5 \% \mathrm{CP}$.

Table (4): Nutritional analysis of concentrate mixture used in the Experimental treatments and sugar cane bagasse (g/kg DM) offered to the lactating buffaloes.

\begin{tabular}{lcccc}
\hline Nutrient & \multicolumn{3}{c}{ Treatments } \\
\cline { 2 - 5 } & T1 (CM) & T2 (CM+3.4\% PO) & T3 (CM+5.24\%PO) & SCB \\
\hline Dry matter & 868.0 & 872.2 & 874.3 & 874.3 \\
Organic matter & 910.1 & 910.4 & 910.7 & 966.3 \\
Crude protein & 172.5 & 166.0 & 163.4 & 20.6 \\
Ether extract & 47.6 & 81.3 & 98.0 & 9.9 \\
Carbohydrate & 690.0 & 663.1 & 649.3 & 935.8 \\
NDF & 392.1 & 390.3 & 389.4 & 825.0 \\
ADF & 232.5 & 231.4 & 230.9 & 579.7 \\
Hemicellulose & 159.6 & 158.8 & 158.5 & 245.3 \\
NFC & 297.9 & 272.8 & 259.9 & 110.8 \\
Ash & 89.9 & 89.6 & 89.3 & 33.7 \\
\hline
\end{tabular}

SCB = sugar cane bagasse $(\mathrm{g} / \mathrm{kg} \mathrm{DM})$ offered to the lactating buffaloes.

$N D F=$ neutral detergent fibre $A D F=$ acid detergent fibre $\quad N F C=$ non-fibrous carbohydrates $\quad S C B=$ sugar can bagasse.

Addition of PO as $10 \%$ (T2) or $15 \%$ (T 3) increased the EE concentrations by 33.7 and 50.4 (g/kg $\mathrm{DM})$. In this experiment $\mathrm{PO}$ was used as a source of fat to increase the dietary energy density in the ration of lactating buffaloes by 10 and $15 \%$ of their ME requirements according to AFRC (1993) standards. 
Accordingly the EE of the CM increased from 47.6 to 81.3 and $98.0 \mathrm{~g} / \mathrm{kg}$ DM. It is reported in NRC (2001) that the total content of EE in the CM should not exceed 70-90 g/kg DM. However the EE content in the total ration on DMI basis were 32.84, 54.28 and $64.52 \mathrm{~g} / \mathrm{kg}$ (Table 6) which is in the normal range of this type of studies. Concentrations of other nutrients in the three experimental CMs were almost the same despite the slightly lower concentrations of NFC and CHO in T2 and T3 than in T1 the control CM (Table 6). Sugar cane bagasse was characterized by its lower content of CP $20.6 \mathrm{~g} / \mathrm{kg}$ DM and higher concentrations of fibre fractions (NDF, ADF and hemicellulose) compared with the CM (Table 4).

Table (5): Dry matter intake (DMI kg/day) of lactating buffaloes fed the experimental treatments.

\begin{tabular}{lccccc}
\hline \multirow{2}{*}{ Item } & \multicolumn{5}{c}{ Treatments } \\
\cline { 2 - 6 } & T1 & T2 & T3 & S.E.M. & Sig \\
\hline Concentrate mixture & 7.82 & 7.94 & 8.40 & & \\
Fat supplement & ---- & 0.27 & 0.44 & & \\
Concentrate mixture +Fat & 7.82 & 8.21 & 8.84 & 0.67 & NS \\
Sugar can bagasse & 5.03 & 5.00 & 5.42 & 0.48 & NS \\
Total dry matter intake & 12.85 & 13.21 & 14.26 & 0.62 & NS \\
Concentrate : Roughage ratio & $1.56: 1$ & $1.64: 1$ & $1.63: 1$ & \\
\hline S.E.M. = Standard error mean & Sig=Significance & NS=not significant & &
\end{tabular}

The actual dry matter intake (DMI) of each ration constituent (CM, PO and SCB) is displayed in Table (5). It is clear that fat supplementation increased the total DMI of both CM and SCB. This increment in total DMI represents 2.8 and $10.97 \%$ in T2 and T3 respectively when compared with $\mathrm{T} 1$. The increment in T3 above T2 was $7.95 \%$ in total DMI. Even though, these differences were not statistically significant. The insignificant increase in DMI may be partially explained as animals eat to maintain homeostasis of the gastrointestinal tract fill (Forbes, 2000 and Ellis et al., 2000). Moreover, fat supplementation depresses the propionate inhibitory effect on DMI (Allen, 2000). Mosley et al. (2007) reported that addition of palm fatty acids up to $3.2 \%$ or $0.5 \mathrm{~kg} /$ day increased DMI. The amount of supplemented (PO) represented $0,3.4$ and $5.24 \%$ of the $\mathrm{CM}$ in T1, T2 and T3, respectively.

The concentrate: roughage ratio was nearly similar in the three treatments (Table 5). The calculated concentrations of feed nutrients consumed $\mathrm{g} / \mathrm{kg}$ DM from both $\mathrm{CM}$ and $\mathrm{SCB}$ of the experimental rations are presented in Table (6).

Table (6): Calculated concentrations of nutrients consumed (g/kg DM) from concentrate mixture and sugar can bagasse of the experimental treatments.

\begin{tabular}{lccc}
\hline Nutrient & \multicolumn{3}{c}{ Treatments } \\
& T1 & T2 & T3 \\
\hline Dry matter & 879.3 & 881.5 & 882.9 \\
Organic matter & 932.1 & 931.5 & 931.8 \\
Crude protein & 113.0 & 110.9 & 109.1 \\
Ether extract & 32.8 & 54.2 & 64.5 \\
Carbohydrate & 786.2 & 766.3 & 758.2 \\
NDF & 561.5 & 554.8 & 554.9 \\
ADF & 368.4 & 363.2 & 363.4 \\
Hemicellulose & 193.1 & 191.5 & 191.4 \\
NFC & 224.6 & 211.4 & 203.2 \\
Ash & 67.9 & 68.4 & 68.2 \\
\hline$N D F=$ neutral detergent fibre, $A D F=$ acid detergent fibre NFC $=$ non-fibrous carbohydrate.
\end{tabular}

Addition of PO increased the EE content of the whole ration consumed by 21.5 and $31.7 \mathrm{~g} / \mathrm{kg}$ DM for $\mathrm{T} 2$ and T3 respectively. The concentrations of other feed nutrients in the experimental rations were almost similar despite the slightly lower concentrations of NFC and $\mathrm{CHO}$ in rations contained fat supplement. 
Digestibility coefficients of feed nutrients are presented in Table (7). It is clear that fat supplementation produced significant $(\mathrm{P}<0.05)$ increase in DM, OM, CP, EE, CHO and the TDN values. The increase in fat supplementation level from 0 to 3.4 or $5.24 \%$ of the CM increased the TDN value by 5.78 and $10.56 \%$ for T2 and T3 above T1 and by $4.54 \%$ for T3 above T2. There is a trend of slightly decrease in digestibility of fibre fractions due to fat supplementation. However, these negative changes were not statistically significant (Table 7).

Table (7): Digestibility coefficients and feeding values (g/kg) of the experimental rations fed to lactating buffaloes.

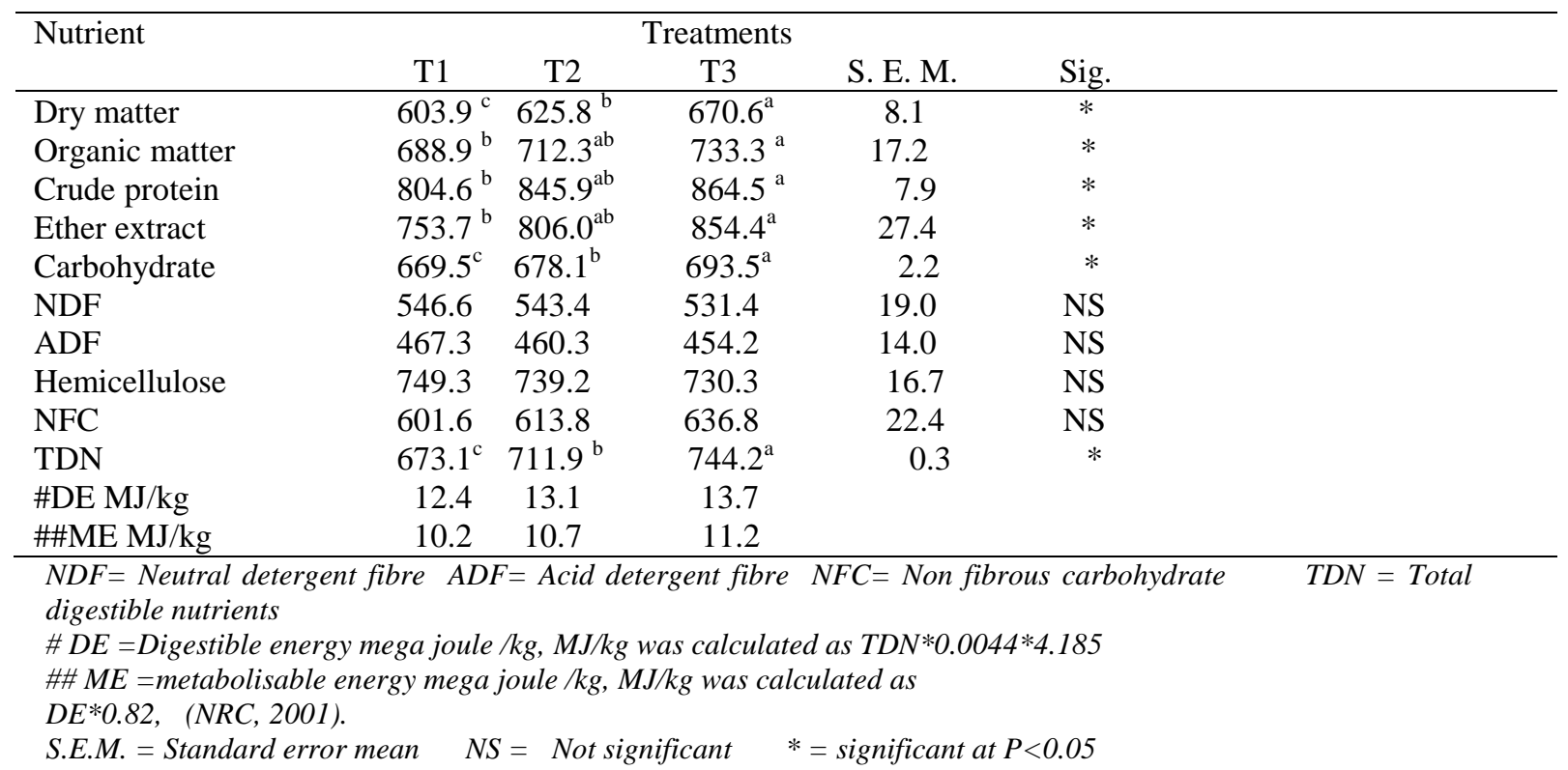

Results of milk yield and milk constituents are presented in Table (8). Fat and level of fat supplementation showed significant $(\mathrm{P}<0.05)$ effect on milk yield, 7\% FCM and 7\% FCM / unit of total DMI. Milk yield was significantly $(\mathrm{P}<0.05)$ increased by 25 and $43.4 \%$ when buffaloes fed T2 and T3 compared with buffaloes fed T1. Moreover, increasing the level of fat supplementation from 3.4 to 5.24 $\%$ of the CM increased the daily milk yield by $14.7 \%$ in T2 $(6.6 \mathrm{~kg} / \mathrm{day})$ compared with T3 $(7.57 \mathrm{~kg} / \mathrm{day}$, Table 8). Applying these correlations on 7\% FCM the enhancement levels were 27.9 and $53.0 \%$ for T2 and T3 above T1. The increment was $19.6 \%$ for T3 above T2. All milk constituents were significantly $(\mathrm{P}<0.05)$ and positively changed except $\mathrm{CP}$, where it was significantly $(\mathrm{P}<0.05)$ reduced, while changes in solid not fat were not significant (Table 8). The increments in fat content $(\mathrm{g} / \mathrm{kg}$ ) were 3.0 and $9.0 \%$ when T2 and T3 were compared with T1. Increasing the level of fat supplementation increased the fat content by $5.8 \%$ inT3 compared with $\mathrm{T} 2$. On the other direction milk $\mathrm{CP}$ was reduced significantly $(\mathrm{P}<0.05)$ by 4.4 and $8.29 \%$, in $\mathrm{T} 2$ and $\mathrm{T} 3$, respectively compared with $\mathrm{T} 1$. When $\mathrm{T} 3$ was compared with $\mathrm{T} 2$ the reduction achieved $4.1 \%$, however the daily protein yield was increased by 19.7 and $31.4 \%$, in T2 and $\mathrm{T} 3$ respectively, compared with $\mathrm{T} 1$. The improvement level was $9.9 \%$ for $\mathrm{T} 3$ above $\mathrm{T} 2$. The significant depression in concentration of milk protein due to fat supplementation (Table 8) could be explained as the fat supplementation was not accompanied with a protein source supplementation .The milk yield was increased, but the available amino acids are limited despite the greater protein intake through the insignificant increase in DMI and the significant enhancement in CP digestibility. Moreover, the significant improvement in carbohydrate and insignificant increase in NFC digestibility leading to higher concentrations of carbohydrate end products in blood plasma (glucose, Table 9) that may save using protein as a source of energy but secreted in milk. Vandeharr (2005) reported that $20-40 \%$ of gluconeogenesis comes from amino acids. This sparing action led to more efficient utilization of absorbed amino acids to be used in milk protein synthesis. Therefore the daily milk protein yield was increased due to fat supplementation and according to the level of supplementation. 
The daily yield of milk fat was significantly $(\mathrm{P}<0.05)$ and positively changed from 0.383 to $0.493 \mathrm{~kg}$ and 0.598 , in buffaloes fed $\mathrm{T} 1, \mathrm{~T} 2$ and $\mathrm{T} 3$ respectively. The corresponding figures for daily yield of milk lactose were $0.228,0.288$ and 0.344 for $\mathrm{T} 1, \mathrm{~T} 2$, and $\mathrm{T} 3$ respectively (Table 8). The changes in lactose yield $(\mathrm{kg} / \mathrm{day})$ were significant $(\mathrm{P}<0.05)$. The increment was 26.3 and $50.9 \%$ in $\mathrm{T} 2$ and $\mathrm{T} 3$ respectively, compared with $\mathrm{T} 1$, and was $19.44 \%$ inT3 compared with $\mathrm{T} 2$. The ME concentration of these rations as calculated from TDN values were 10.16, 10.74 and $11.22 \mathrm{MJ} / \mathrm{kg}$ DM. The increment in ME concentration was 5.7 and $10.43 \%$ for T2 and T3 compared with the control ration T1 (Table 7). This increase in ME consumed that is due to the increment in the ME density of the ration and enhancement digestibility of feed nutrients may enabled the productive processes of animal tissues and mammary gland in particular to synthesize and secret more milk constituents.

Table (8): Milk yield and milk constituents of lactating buffaloes fed the experimental treatments.

\begin{tabular}{|c|c|c|c|c|c|}
\hline \multirow[t]{2}{*}{ Item } & \multicolumn{3}{|c|}{ Treatments } & \multirow[b]{2}{*}{ S.E.M. } & \multirow[b]{2}{*}{ Sig. } \\
\hline & $\mathrm{T} 1$ & $\mathrm{~T} 2$ & $\mathrm{~T} 3$ & & \\
\hline Milk yield (kg/day) & $5.28^{c}$ & $6.60^{b}$ & $7.57^{\mathrm{a}}$ & 0.33 & $*$ \\
\hline $7 \%$ FCM " " & $5.42^{\mathrm{c}}$ & $6.93^{b}$ & $8.29^{a}$ & 0.17 & $*$ \\
\hline 7\% FCM / TDMI & $0.42^{\mathrm{c}}$ & $0.53^{\mathrm{b}}$ & $0.58^{\mathrm{a}}$ & 0.01 & $*$ \\
\hline \multicolumn{6}{|c|}{ Milk constituents $(\mathrm{g} / \mathrm{kg})$} \\
\hline Fat & $72.5^{c}$ & $74.7^{\mathrm{b}}$ & $79.0^{\mathrm{a}}$ & 0.06 & $*$ \\
\hline Protein & $43.4^{\mathrm{a}}$ & $41.5^{b}$ & $39.8^{c}$ & 0.01 & $*$ \\
\hline Lactose & $43.2^{b}$ & $43.6^{\mathrm{b}}$ & $45.4^{\mathrm{a}}$ & 0.01 & $*$ \\
\hline Ash & $8.1^{\mathrm{c}}$ & $9.1^{\mathrm{b}}$ & $9.5^{\mathrm{a}}$ & 0.01 & $*$ \\
\hline Total solids & $67.2^{b}$ & $168.9^{b}$ & $173.7^{\mathrm{a}}$ & 0.03 & $*$ \\
\hline Solid not fat & 94.7 & 94.2 & 94.7 & 0.05 & $*$ \\
\hline \multicolumn{6}{|c|}{ Yield of milk constituents (kg/day) } \\
\hline Fat & $0.383^{c}$ & $0.493^{b}$ & $0.598^{\mathrm{a}}$ & 0.001 & $*$ \\
\hline Protein & $0.229^{c}$ & $0.274^{b}$ & $0.301^{\mathrm{a}}$ & 0.001 & $*$ \\
\hline Lactose & $0.228^{\mathrm{c}}$ & $0.288^{b}$ & $0.344^{\mathrm{a}}$ & 0.001 & $*$ \\
\hline
\end{tabular}

Results of some blood metabolites concentrations are displayed in Table (9). Glucose, total protein, total lipids, cholesterol and triglycerides in blood plasma were increased significantly $(\mathrm{P}<0.05)$ due to fat supplementation. The concentrations of glucose were 57.25, 65.0 and $71.50(\mathrm{mg} / \mathrm{dl})$ for T1, T2 and T3, respectively. The corresponding concentrations of total protein were $7.08,7.15$ and $7.25 \mathrm{~g} / \mathrm{dl}$, respectively. Total lipid concentrations were 395.0, 442.5 and $497.5(\mathrm{mg} / \mathrm{dl})$ for $\mathrm{T} 1, \mathrm{~T} 2$ and $\mathrm{T} 3$, respectively. Differences in cholesterol level were 51.8 and $118.8 \%$ for T2 and T3 above T1. Fat supplementation increased triglycerides concentrations by 50 (T2) and 90\% (T3) above (T1). Increasing the level of supplementation was accompanied with an increase in plasma triglycerides concentration by 27.3\%. In other words the blood metabolites (total protein, total lipids, cholesterol, triglycerides and glucose) concentrations were enhanced due to fat supplementation. These increases provided sources for milk constituent's synthesis, concomitantly the yield of milk constituents were increased (Tables 8 and 9).It was noted that PO supplementation increased EE content and digestibility. These mean greater portions of fatty acids and lipid constituents were available for mammary gland tissues to synthesis de novo fatty acids to be secreted in milk leading to greater fat content in milk and significantly greater yield of milk fat (Table 8). This result was in agreement with Drackley et al. (2003), Rabiee et al. (2012), Mahendra et al. (2014) and Stoffel et al. (2015). They stated that increased energy density from either fat or concentrates increased milk yield in mid-lactating cows. In addition Baldwin et al. (1980) reported that incorporation of preformed long-chain fatty acids, (LCFA) into milk fat is energetically more efficient than de-novo synthesis of LCFA from acetate. In the present work, PO used contained considerable proportions of C16, C18:1 and total unsaturated fatty acids. Moreover, Grummer and Carrol (1991) reported that fat supplementation may also alter the endocrine profile in a manner that favors milk synthesis. 
Fat supplementation increased $\mathrm{t}_{3}$ (Triiodothyronine) hormone concentrations significantly $(\mathrm{P}<0.05)$ by 13.16 and $21.05 \%$ upon feeding T2 and T3 respectively as compared with $\mathrm{T} 1$. The difference in $t_{3}$ concentration between T2 and T3 was not significant. Thyroxin $\left(\mathrm{t}_{4}\right)$ concentration was increased due to fat supplementation. The figures were 41.54, 53.08 and $54.40 \mathrm{ng} / \mathrm{ml}$. The differences were not significant. It is of interest to find an increase in thyroid hormones concentrations $\left(t_{3}\right.$ and $\left.t_{4}\right)$ due to fat supplementation. It is well known that thyroid hormones are generally related to metabolic rate and energy metabolism in particular. This result is in agreement with the observed increment in blood metabolites concentrations and DMI. Bayoumi (1995) found that the increase in feed intake of dairy buffaloes and cows was associated with increase in their serum $t_{3}$ and $t_{4}$ concentrations.

Table (9): Concentrations of some blood metabolites and thyroid hormones of lactating buffaloes fed the experimental rations.

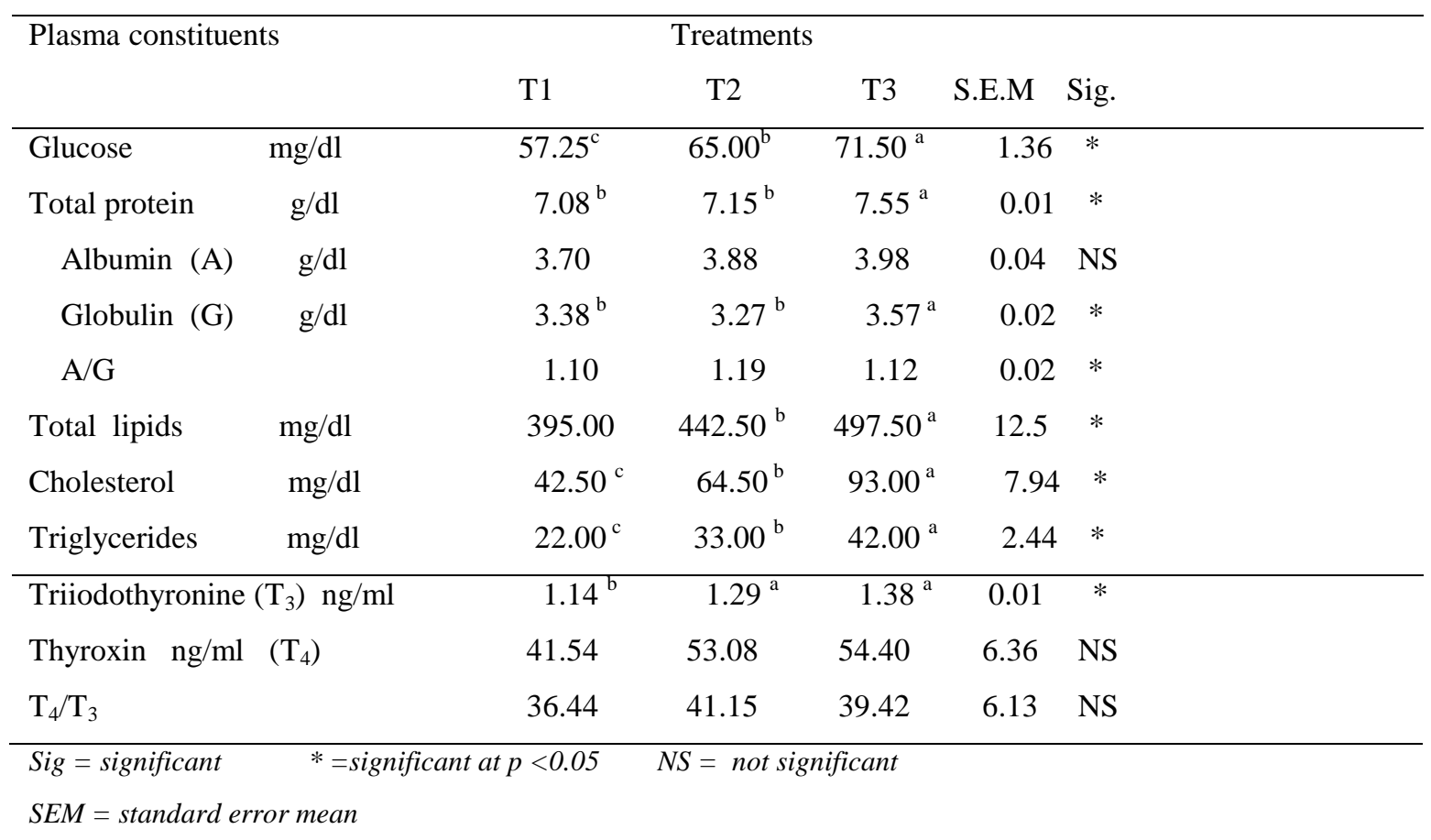

All these changes may indicate that ME requirement of lactating buffaloes is greater than that outlined by AFRC (1993) for dairy cattle and buffalo feed nutrients requirements should be studied deeply. On the hand, Paul et al. (2003) concluded that amounts of dry matter, digestible CP and ME required for one $\mathrm{kg}$ FCM production were significantly lower in buffaloes than cows.

It could be extracted from the present pilot experiment that $\mathrm{PO}$ as a source of fat in amount up to $5.24 \%$ of the CM consumed enabled the productive ability of these buffaloes to expresses themselves through greater DMI, better metabolisability and more efficient utilization of blood metabolites in synthesis of milk constituents. Kronfeld (1976) and Jenkins (1997) indicated that milk production reaches its maximal efficiency when fatty acids constitute $16 \%$ of ME that represent $600-700 \mathrm{~g}$ supplemental fat. In our pilot study the highest production level was achieved when $440 \mathrm{~g}$ of PO was supplemented (Table 5). This means that increasing the level of fat supplementation may have positive effect on dairy buffalo's productivity.

The economical feature (Table 10) indicated that PO supplementation increased the total daily feed intake cost by 10.6 and $22.28 \%$, but in a positive direction the daily yield of $7 \%$ FCM was increased by 27.86 and $52.95 \%$ according to the level of PO supplementation. These encouraging results led the balance (selling price - total feed coast) changed from 5.47 to 8.39 and 10.85 (LE/d). In other words, the 
superiority (enhancement in money return) due to PO (10 and $15 \%$ ) supplementation was 53.38 and $98.35 \%$ respectively above the control diet. The results obtained were in agreement with Rabiee et al. (2012). They concluded that fat could improve the efficiency of milk production.

Table (10): Economical feature of feeding the experimental rations to the lactating buffaloes

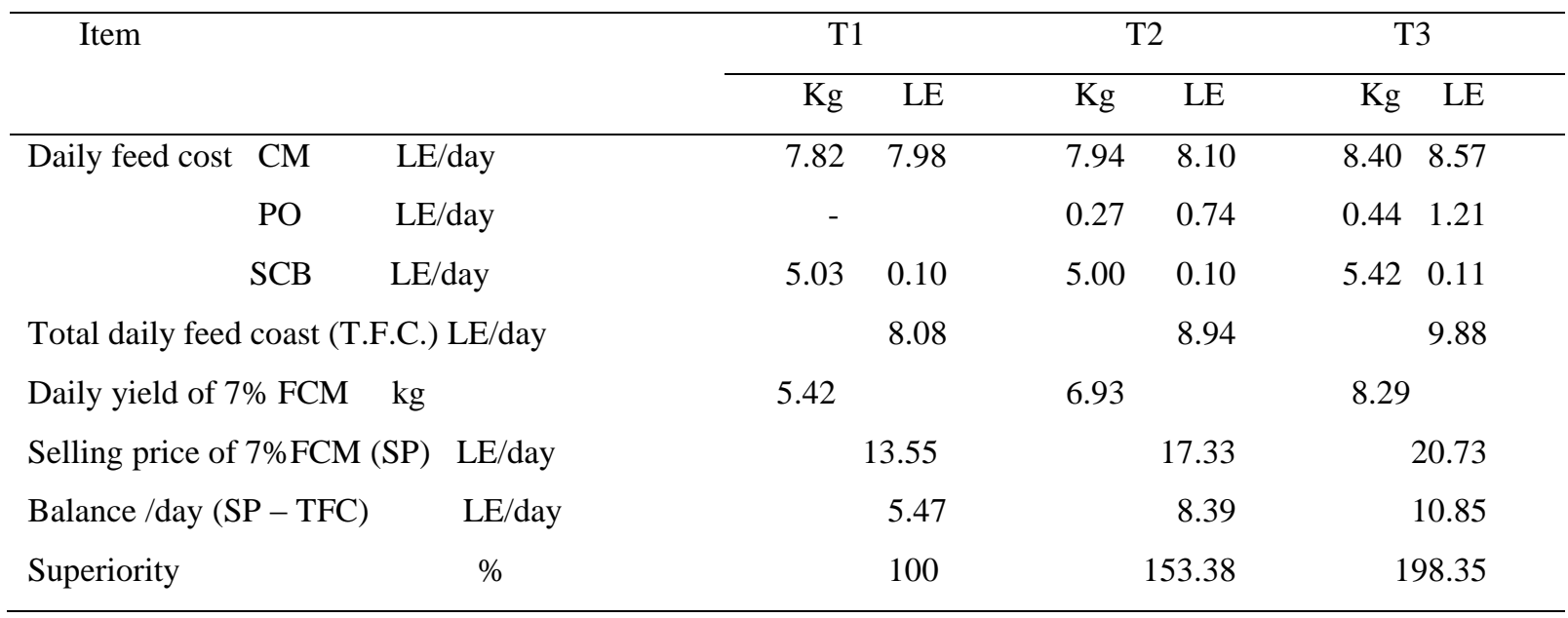

The price of one kg FCM (buffalo's milk) at the time of experiment was 2.5 LE (Egyptian pound)

\section{CONCLUSION}

The results of this experiment were encouraging and can be built on in terms of adding source of fat to lactating animals and it would be more applicable when using greater number of animals and different sources of fat. Source of protein need to be added to balance between energy and protein available for milk constituent's synthesis. Fatty acids profile of fat supplemented source and milk fat interrelation should looked at to find out what is healthier for humans and acceptable to milk products manufactures.

\section{REFERENCES}

A.O.A.C. (1990). Official methods of analysis (15th. Ed) Association of Official Analytical Chemists, Arlington, USA.

AFRC (1993). Agriculture and Food Research Council, Energy and protein requirements of ruminants. An advisory manual prepared by the AFRC Technical committee on responses to nutrients. Chapter two, Requirements for metabolisable energy, pp. 21- 32. CAB international, Wallingford, OX 10 8DE, U.K.

Allen M.S. (2000). Effects of diet on short-term regulation of feed intake by lactating Cattle, Journal of Dairy Science 83: 1589 - 1624.

Baldwin R.L., N.E. Smith, J. Taylor and M. Sharp (1980). Manipulating metabolic parameters to improve growth rate and milk secret. Journal of Animal Science, 51: 1416 -1428.

Bayoumi, H.M. (1995). Productive and reproductive performance of Egyptian buffaloes as affected by feeding level during mid-pregnancy and early stage of lactation. M.Sc. Thesis Anim. Prod. Dept. Fac. of Agric. Moshtohor, Banha branch, Zagazig Univ. Egypt.

British Standards Institution (1962). British standard methods for determination of milk fat, the Gerber method. Bullg P. 962.

Drackley, J.K., T.M. Cicela and D.W. Lacount (2003). Responses of primiparous and multiparous Holstein cows to additional energy from fat or concentrate during summer. Journal of Dairy science 86, 1306 - 1314. 


\section{Fahmy et al.}

El-Ashry MA, Khattab HM, Alamy HA, Kholif AM and Abo-Elnour SAH (1992). Effect of feeding varying Levels of Luciana on productive performance of ruminants. 2- Effect of replacing concentrates with Luciana hay on some blood parameters of lactating buffaloes. International center for Agriculture, Doki, Cairo, Egypt 9-12 November.

Ellis WC, Poppi D and Matis JH 2000. Feed intake in ruminants: Kinetic aspects in farm animal metabolism and nutrition, Chapter 16, P 335 - 364, Mello DJPF,CABI,UK.

Forbes JM 2000. Physiological and metabolic aspects of feed intake control in farm animal metabolism and nutrition. Chapter 15, P 319 - 334, Mello D JPF,CABI, UK.

Gill JL and Magee WT 1976. Balanced two period's changeover designs for several treatments. Journal of Animal science 42, 775 -777.

Grummer RR and Carrol DJ 1991. Effects of dietary fat on metabolic disorders and reproductive performance of dairy cattle. Journal of Animal science, 69: 3838-3852.

Ibrahim, E.M. 2001. Some physiological responses of dairy cattle fed different Levels of dietary energy. M. Sc. Thesis Fac. of Agric., El-Minia Univ,.., Egypt.

Jenkins TC 1997.Success of fat in dairy rations depends on the amount. Feedstuffs 69,11 -12.

Juchem SO, Santos JEP, Cerri RLA, Chebel RC, Galvao KN, Bruno R, Peters EJDe, Scott T, Thatcher WW and Luchini D 2008. Effect of calcium salts of fish and Palm oils on at lactational performance of Holstein cows. Journal of Animal feed science and technology 140, 18-38.

Kearl LC 1982. Nutrient requirements of ruminants in developing Countries International Feed Stuffs Institute, Utah Agriculture Experimental Station, Utah State University, Logan Utah, USA. In Option Mediterranean's, series A, No 67, P271, CIHEAM, Paris

Kronfeld DS 1976. The potential of the proportions of glucogenic, lipogenic and aminogenic nutrients in regard to the health and productivity of dairy cows, Advanced animal physiology and animal nutrition $7,5-26$.

Mahendra Singh, J.P. Sehgal, A.K.Roy, S.Pandita and G.Rajesh 2014. Effect of prill fat supplementation on hormones, milk production and Energy metabolites during mid-lactation in crossbred cows. Veterinary world 7 (6):384-388.

Mosley SA, Mosley EE, Hatch B, Szasz JI, Corato A, Zacharias N, Howes D, and McGuire MA 2007. Effect of varying levels of fatty acids from palm oil on feed intake and milk production in Holstein cows. Journal of Dairy science 85, 987-993.

Ministry of Agriculture and land reclamation, livestock numbers and kinds At governorates, year 2010, Animal wealth development sector, Economic affairs sector (EAS), June 2011.

Nanda, A.S. and T. Nakao (2003) .Role of buffalo in the socio economic development of rural Asia: Current status and future prospectus,Anim. Sci.J.,74: 443-455.

Nawaz, H., M. Abdullah, M. Yaqoop, M.E.Babar, M.A. Jabbar and M. Tariq 2012. Metabolic effects of feeding different sources of supplemental fat to lactating Nili-Ravi buffaloes The Journal of Animal and Plant Sciences, 22 (3 Suppl.): 2012 Page: 288-295

NRC 2001. National research council, Nutrient requirements of dairy cattle. 7th rev. Ed. National Academy Press, Washington, DC.USA.

Pathak NN and Verma DN 1993. Nutritional requirements of buffaloes, Lucknow,India. International Books Distributors Co. Ltd.

Paul SS, Mandal AB, Kannan A, Mandal GP and Pathak NN (2003). Comparative dry matter intake and nutrient utilization efficiency in lactating cattle and buffaloes. Journal of Science of Food and Agriculture 83, 258-267.

Paul SS, Mandal AB, and Pathak NN 2002. Feeding standards for lactating riverine buffaloes in tropical conditions. Journal Dairy Research, 69: $173-180$.

Raafat, NA and Saleh M 1962. Two formulas for the conversion of cow's milk and buffalo's milk of different fat percentages into milk of standard fat percentage. Proceeding of the $1^{\text {st }}$ Animal production conference at Minia, Egypt: 203. 
Rabiee, K.Breinhild, W.Scott, H.M.Golder, E.Block and I.J.lean (2012). Effect of fat additions to diets of dairy cattle on milk production and components: A meta - analysis and meta - regression. J Dairy Sci. 95,3225 - 3247 .

Radwan SS 1978. Coupling of two dimension thin layer chromatography with gas chromatography for the quantitative analysis of lipid classes and their constituent fatty acids. Journal of Chromatography Science $16,538-542$.

Rajesh G., Mahendra Singh, A.K. Roy and Sukhjinderjit Singh (2014). Effect of prilled fat supplementation on milk yield composition and plasma hormones in early lactation crossbred cows. J.Bio.Innov 3 (4): 216 - 224,2014

Ranjhan SK 1980. Animal Nutrition in the Tropics, chapter 13 Nutrient requirements and feeding of dairy cattle and buffaloes pp $224-266,3^{\text {rd }}$ ed, New Delhi, India Vikas Publishing House.

SAS, 1990. SAS Users Guide, Statistics, Version 5 Ed. SAS Institute, INC., Cary, NC., USA.

Stoffel, C.M.,P.M.Crumpand L.E.Armentano 2015. Effect of dietary fatty Acid supplements, varying in fatty acid composition on milk fat secretion in dairy cattle fed diets supplemented to less than $3 \%$ total fatty acids J.Dairy Sci.98 : 431- 442

Tomlinson AP, Vanhorn HH, Wilcox CJ, and Harris BJr, 1994. Effects of undegradable protein and supplemental fat on milk yield and composition and physiological responses of cows. Journal of Dairy Science 77, 145-156.

Tripathi, M.K. 2014. Effect of nutrition on production, composition, fatty acids and nutraceutical properties of milk. J. Adv. Dairy Res. 2014, 2:2http://dx.doi.org/ 10.417212329-888x.1000115

Vandeharr JJM, 2005. Dairy cattle in: Basic Animal Nutrition and Feeding, $5^{\text {th }}$ ed. Pond WG, Church DC, Pond KR and Schoknecht PA, PP 413 - 437, Published by John Wiley and Son, Inc. USA.

Van Keulen J and Young BA 1977. Evaluation of Acid insoluble ash as a natural marker in ruminant digestibility studies. Journal of Animal science 44,282 - 287.

Van Soest PJ, Robertson JB and Lewis BA 1991. Methods for dietary fiber, neutral detergent fiber and nonstarch polysaccharides in relation to animal nutrition. Journal of Dairy science 74, 3583 - 3597 .
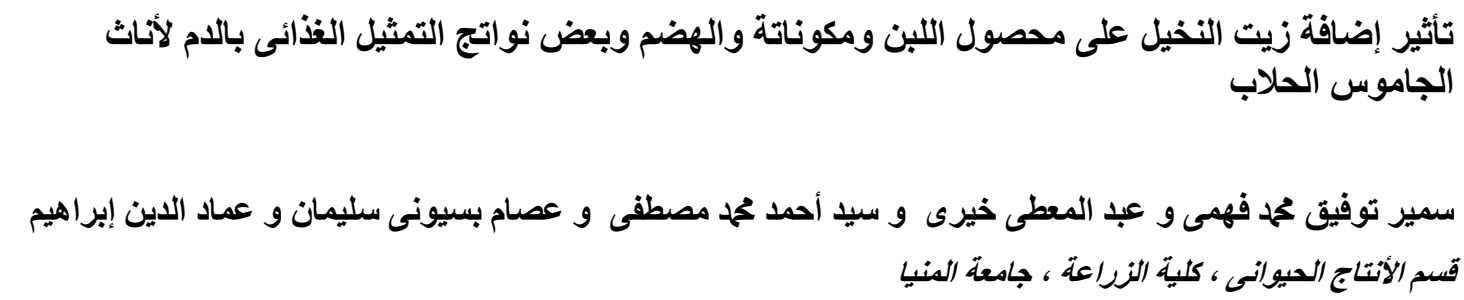

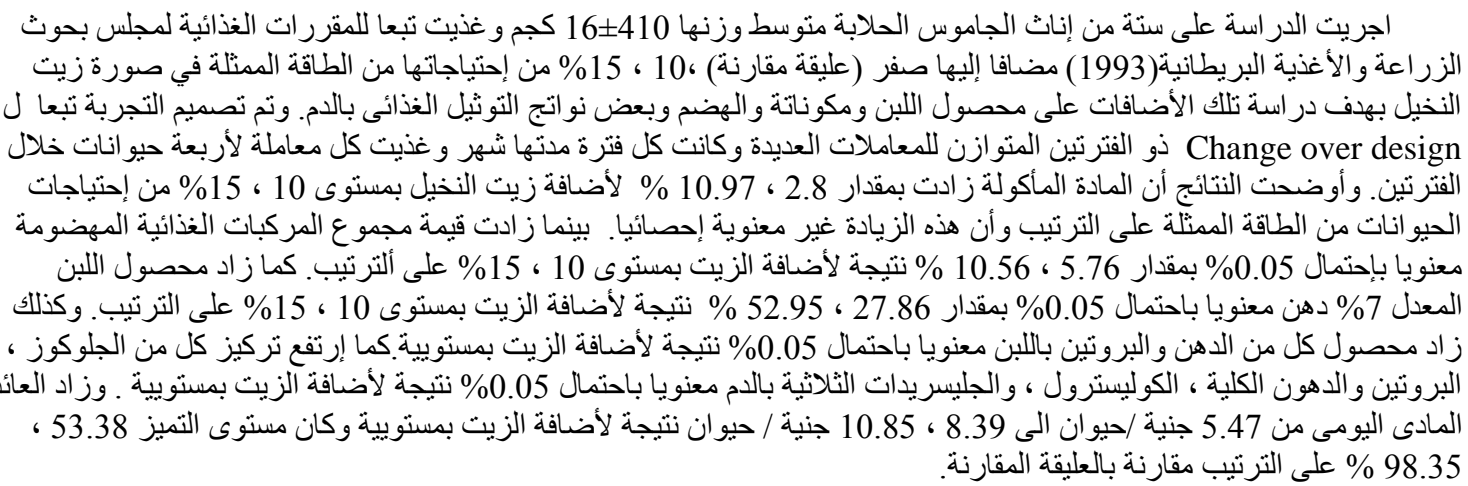

